\title{
The Value of C Reactive Protein and the Leukocytes in the Peritoneal Fluid in the Predicting Postoperative Digestive Fistulas
}

\author{
Virgiliu-Mihail Prunoiiu,2, Augustin Marian Marincaș, ${ }^{1,2}$ Rossana Brătucu ${ }^{1,2}$, Eugen Brătucu ${ }^{1,2}$, Sinziana Ionescu ${ }^{1,2}$, \\ Maria-Manuela Răvaș ${ }^{1,2}$, Ileanu Bogdan Vasile ${ }^{3}$ \\ ${ }^{1 " C a r o l ~ D a v i l a " ~ U n i v e r s i t y ~ o f ~ M e d i c i n e ~ a n d ~ P h a r m a c y, ~ B u c h a r e s t, ~ R o m a n i a ~}$ \\ ${ }^{2} 1^{\text {st }}$ Clinic of General Surgery and Surgical Oncology, Bucharest Oncology Institute, Romania \\ ${ }^{3}$ The Bucharest University of Economic Studies, Department of Statistics and Econometrics, Bucharest, Romania
}

Corresponding author:

Augustin Marian Marincaș, MD

1st Clinic of General Surgery and Surgical Oncology, Bucharest Oncology Institute, Romania

E-mail: marian_marincas_11@yahoo.com

\section{Rezumat}

Valoarea proteinei $C$ reactive și a leucocitelor din lichidul peritoneal in predictia fistulelor digestive postoperatorii

Introducere: Fistulele anastomotice în chirurgia digestivă reprezintă o complicație gravă, care poate duce la decesul pacientului. Identificarea unor probe paraclinice de laborator care să permită diagnosticul precoce al fistulelor ar permite optimizarea managementului pacientului.

Metodă: Noi am efectuat un studiu prospectiv pe 100 pacienți cu cancer, operați pe tubul digestiv, între mai 2016 şi decembrie 2017 , în Clinica I de Chirurgie Generală şi Oncologică a Institutului Oncologic din Bucureşti (IOB). Urmărirea postoperatorie a inclus determinarea proteinei $\mathrm{C}$ reactive $(\mathrm{PCR})$, monitorizarea numărului de leucocite $(\mathrm{Ld})$ din cavitatea peritoneală (din produs biologic recoltat de pe tubul de dren), asociat cu numărul de leucocite din sânge (Ls) la toți pacienții cu sau fără fistulă digestivă. În funcție de valorile acestor probe biologice şi de evoluția clinică, în cazuri selecționate s-au asociat alte explorări paraclinice pentru confirmarea diagnosticului.

Rezultate: Datele obținute au arătat că la pacienții cu fistule digestive are loc o creştere rapidă şi o menținere la valori ridicate a PCR şi a leucocitelor din cavitatea peritoneală, la care s-a asociat şi o creştere a leucocitelor din sânge. Modificările apar cu aproximativ două zile înainte de apariția semnelor clinice şi a confirmării lor prin probe imagistice (ecografie, computer tomograf). 
Concluzie: monitorizarea regulată şi standardizată în zilele 1,3 şi 5 postoperator a valorii PCR, a numărului leucocitelor din cavitatea peritoneală şi a leucocitozei, permite identificarea precoce a pacienților cu risc de fistulă şi selectarea rapidă a celor care necesită explorări suplimentare şi/sau intervenție chirurgicală.

Cuvinte cheie: proteina C reactivă, număr leucocite lichid peritoneal, leucocitoză, chirurgie digestivă, complicații postoperatorii, fistulă anastomotică

\section{Abstract}

Introduction:Anastomotic fistulas in digestive surgery are a severe complication of the patient. The identification of paraclinical laboratory investigations which would allow an early diagnosis of fistulas would lead to the optimization of patient's management.

Methods: We have performed a retrospective study on 100 cancer patients, with digestive tract surgeries, between May 2016 and December 2017, in the First Clinic of General surgery and Surgical Oncology from the Bucharest Oncology Institute. The postoperative follow-up included: the testing of the $\mathrm{C}$ reactive protein (CRP), and also the monitoring of the number of leukocytes (Ld) from the abdominal cavity, with probes taken from the drainage tube, all in association with the number of leukocytes in the blood (Ls) in all patients (with or without digestive fistula). By calculating the values of these tests and comparing them always with the clinical evolution of the patients, and sometimes with other tests as well, one would confirm an early diagnosis of fistula. Results: The data obtained have shown that in patients with digestive fistulae there is a rapid growth and maintaining of increased values of serum PCR and of the leukocytes from the peritoneal cavity, values to which we associated also an increase in blood leukocytes. The modifications appear with approx. two days before the appearance of clinical signs or their confirmation through imagery (ultrasound, computed tomography).

Conclusions:The regular and standardized follow-up in days 1, 3 and 5 postoperatively of the PCR value in blood, of the number of leukocytes in the abdominal cavity and of the serum leucocytosis, increasing the value of these parameters, could allow the early identification of the patients with a risk of fistula and the rapid selection of those which need supplementary investigations and/or surgical intervention.

Key words: $\mathrm{C}$ reactive protein, peritoneum leukocytes, leukocytosis, digestive surgery, postoperative complications, anastomotic fistula

\section{Introduction}

Anastomotic fistulas in colorectal surgery are a severe complication, which can lead to the death of the patient. The colon has a modest vascularization (1) and a great endoluminal septicity. The success of an anastomosis depends on two factors: the surgical technique and the biologic potential (local and general). At the same time, the number of low colorectal and colo-anal anastomosis increased with the use of mechanical anastomosis. The implementation in the last years of new methods like laparoscopic and robotic surgery, did not help in reducing the incidence of fistulas.

In 1987, Vignal J. et al. analysed the following factors: age, type of the disease, type of surgery, type of anastomosis, the localization of anastomosis, the type of the resection, the protection colostomy, and the type of suture. The findings were: in patients over 65 years old the complication is more frequent, 
but not statistically significant; the patient with cancer has a greater significant risk of fistula, its incidence after the anterior rectum resection being of $10.8 \%$, the incidence in the manual suture was of $10 \%$ and in the mechanical suture of $8 \%$, the incidence of fistulas in the anastomosis of the small intestine and ileo-colic bowel was of $1 \%-2 \%$, the incidence of colo-anal fistulas was of $10 \%-20 \%$, the total fistula incidence being of $2.9 \%$ (2).

The current definition of colorectal anastomotic leak is given by Muller in 1994 and includes: exteriorization of faeces through the wound, fever over $38^{\circ} \mathrm{C}$, radiological or endoscopic signs of fistula, intraperitoneal abscess or peritonitis in the presence of a fistula (3). All these signs appear tardily, when the septic intraperitoneal process has already started.

From the socio-economic point of view, these severe septic complications lead to the increase of mortality $(6 \%-22 \%)$ and general morbidity $56 \%$ (4) and to the increase of costs of the medical care (5). It is necessary to establish some biologic criteria which could early identify postoperatively the patients having a potential risk for fistula $(6,7)$.

The purpose of this study is trying to establish a way of rapidly diagnosing fistulas in the preclinical and preimaging phase, and in this way, to suggest a more rapid and efficient therapeutic attitude to prevent the apparition of the risk of faecal peritonitis. Finding less costly biologic markers which could be included in a score with high predictability could allow the application of early and efficient measures $(8,9,10)$.

Our aim extend to fistulas, which appear after gastrointestinal surgery, hence after a surgery where the septic factor is considerably more modestly expressed. The unpredictable behaviour of the oesophagus and of the duodenal stump after esophago-jejunal anastomosis and duodenal suture is well known. Mechanical or manual, the anastomotic suture and the congested duodenal stump still create a notable risk for the emergence of fistulas.

CRP and the study of leukocytes from the peritoneal fluid are the early response of the peritoneum at the germ aggression in the moment the fistula is produced. CPR is the most studied marker of the inflammation and it is used in assessing the anastomotic leakage score (Dutch Leakage Score) (9).

We organize the paper as follows: Section 1. Data, material and methods, Section 2. Results and in the 3rd section we present Conclusions and Discussions.

\section{Material and Methods}

The objectives of the paper are: postoperative identification of CPR value in the blood quantitative dosing of leukocytes from the fluid in the peritoneal drain collected postoperatively $/ 24 \mathrm{~h}$ from the patients having digestive anastomosis after cancer surgery (colorectal or gastric cancer).

Measuring the leukocytosis in the blood establishing a prediction score which allows the identification of the anastomotic fistula before the apparition of septicaemia, secondary to the apparition of abscess or peritonitis CRP and the study of leukocytes from the peritoneal fluid are the early response of the peritoneum at the germ aggression in the moment the fistula is produced.

CRP is being dosed with the help of Konelab 600 device, and the leukocytes are quantitatively measured with CYBOW 720 device. The devices are owned by the Oncology Institute in Bucharest - IOB, and they are state-of-the-art readers, easy to use and reliable, characteristics which assure the performance and rapidity of the diagnosis.

The studied batches were the following: a sample of 100 patients. From total sample, 59 patients with colon and rectum cancer, 26 patients with gastric cancer, 15 patients with other types of digestive tumours.

We prospectively studied the values of CRP (normal $=0.0-5.0 \mathrm{mg} / \mathrm{dl}$ ) and of leukocytes from the fluid in the peritoneal drain (Ld) (normal $=0-250 / \mu \mathrm{l}$, in the bacterial peritonitis $>250 / \mu \mathrm{l}$ ) associated with the values of leukocytes in the blood (Ls) (normal $=4000-11000 / \mu \mathrm{L}$ ) in the first, third and fifth postoperative day. For a small number of patients (2) the values of $\mathrm{Ld}$ in the $3^{\text {rd }}$ was non-detectable. The biological 
samples and analyzes performed and presented in the article are usually taken in hospitalized and operated patients (blood, peritoneal drainage fluid) and for which patients sign that they agree at the time of admission (The statement of informed consent).

We compared these values in patients with favourable evolution with the data gathered from those with unfavourable evolution (fistula, death). Through this study we wish to surprise the emergence of the fistula before the emergence of clinical (peritonitis) and imaging (CT scan) signs. In the sample we have to sub-groups: one represented by the patients with fistula $\left(\mathrm{n}_{1}=17\right)$ and two, patients without fistula $\left(\mathrm{n}_{2}=83\right)$. The analysis is structured in three stages:

\section{Stage 1}

First we compare the median CRP and Ld values of two groups of patients: patients with fistula vs. patients with no fistula. While the assumption of normality is rejected we use the independent sample Median test, to test the difference between groups.

Then we are interested to measure the values of the CRP and Ld in day 1, 3, 5 and 7 for each sub-group and to see if there are some significant differences at different time points. Here, we use the non-parametric tests fore related samples, such as Wilcoxon signed rank and the Sign test to complete the analysis, since the distribution of the patients by CRP or Ld values cannot be assumed normal in each day $(21,22)$

\section{Stage 2}

We scan value of Ld in the third day (Ld3) and CRP in the third day (CRP3) using the ROC curve in order to see if one or both variables may predict de future presence of the fistula. We define the variables $\operatorname{Ld} 31=\operatorname{Ld} 3 / \mathrm{Ld} 1$ and CRP31=CRP3/CRP1 as dynamics of the Ld and CRP3 in the $3^{\text {rd }}$ day comparative with 1st day. Using again the ROC curve we search for the impact on the future presence of fistulas. Each time we measure the value of Area under the curve (AUC) and we compare it with the 0.5 value which shows the neutrality of the tested factor.

\section{Stage 3}

We analyzie the relation between main indicators CRP, Ld, Ls in each day (the first, the third, and the $5^{\text {th }}$ ). To test the existence of correlation between the indicators we use the non-parametric rank correlation of Kendall (23). We test if the difference is statistically significant. All Statistical analyses are performed with IBM-SPSS, version 21. All figures and tables are made by the authors using Microsoft Office.

\section{Results}

\section{Results Regarding the Medical Characteristic of the Patients and Future Evolution}

The originality of this study consists in the analysis of two blood biological markers (CRP, leukocytosis) and of a peritoneal biological marker (WBC blood count) in trying to establish a prediction score for anastomotic leaks in patients with digestive cancer. The marker in the peritoneal fluid, drained in the juxta-anastomotic drain, will increase the specificity of results compared to the singular analysis of $\mathrm{C}$ reactive protein, a non-specific inflammation marker. However, eliminating the subjective clinical factors will increase the objectivity of the results. The digestive sutures were mechanical and manual and were not the object of a separate analysis.

There were 59 patients with colon and rectum cancer $(59 \%)$, and the distribution on anatomical segments was the following: 35 patients (59.3\%) with tumours on the left colon (15 on the sigmoid, 14 on the rectum and 6 at the level of the splenic angle of the colon), 24 patients with tumours on the right colon (3 on the hepatic angle, 9 on the ascending colon, 10 on the caecum and 2 tumours on the transversal colon). One patient had a double tumour localization, on the caecum and sigmoid. 6 patients $(10.16 \%)$ presented 
anastomosis leak ( 2 on the rectum, 1 on the hepatic angle and 3 on the splenic angle). 1 patient (1.69\%) having a tumour on the hepatic angle died immediately after surgery.

The fistula was identified through clinical and imagistic investigations (native or contrast medium $\mathrm{CT}$ - collection or sinus tract) on average in the seventh postoperative day. The patient with fistula needed an average of 11.5 days in Intensive Care and totalized 25.83 days of postoperative hospitalization. The patient with fistula died in the eleventh day, 6 days after the emergence of the fistula. In 2 out of the patients mentioned in our study $(33.3 \%)$, the fistulas were treated by reintervention (colostomy, drainage, suture), 4 fistulas being treated through conservative treatment.

We admitted into evidence 26 patients with gastric cancer with the following localization at the level of the stomach: $11(42.30 \%)$ at the level of the gastric body ( 9 with adenocarcinoma and 2 with GIST), 13 with tumours at the level of the antrum (50\%), 2 (7.69\%) had esogastric lesions. 8 patients had a postoperative fistula $(30.76 \%)$ and the localizations were: 7 at the level of the duodenal stump and one at the esojejunal anastomosis. In the case of 3 patients $(37.5 \%)$ a surgical reintervention was performed (drainage, suture), 5 fistulas being treated with conservative treatment. There were 3 postoperative immediate deaths registered (11.53\%).The fistula was identified on average in the 6.62 postoperative day, through clinical and imagistic investigations (native or contrast medium CT - collection or sinus tract)

For 15 patients with pancreas cancer, main bile duct cancer or other types of tumours which were invading the small intestine the entero-enteral, bile duct and gastrojejunal anastomosis were monitored. The location was the following: 2 tumours (13.33\%) at the level of the main bile duct, 7 tumours at the level of the pancreas $(46.66 \%)$ and 6 with the invasion of ileum (40\%). 3 patients presented postoperative fistula $(20 \%)$ and the localization was: 2 at the level of the ileum (in the same patient) and one after cephalic duodenopancreatectomy for a neoplasm at the head of the pancreas and a surgical reintervention was performed (100\%). An immediate postoperative death was registered $(6.66 \%)$ - the patient with cephalic duodenopancreatectomy. The fistula was detected in the 6.33 post- $^{-}$ operative day on average.

From the initial sample 17 patients had postoperative leak (17\%) and 8 of them benefited from surgical reinterventions $(8 \%$ from the total of patients, $47.05 \%$ of all patients with fistulas), the rest of fistulas benefiting from conservative treatment. There were 5 postoperative immediate deaths (5\%). The fistula was identified on average in the 6.65 postoperative day (approximately in the seventh day, with values between the second and eleventh day). The patients with fistula needed an average of 19.25 days in Intensive Care and totalized 27.17 days of postoperative hospitalization.

\section{The Results of the Statistical Analysis Related to the Impact of CRP and Ld on the Future Presence of the Fistulas}

\section{Stage 1}

According to Median Test results, the median values of $\mathrm{CRP}$ are statistically significant higher $(p<0.01)$ for patients with fistula compared with patients without fistula, in each of the $3^{\text {th }}$ and $5^{\text {th }}$ day and no statistical difference was found for the first day $(p=0.11)$. The median values by sub-group are presented in Fig. 1.

In the case of $\mathrm{Ld}$, the values are significantly higher for the patients with fistula only in the fifth day $(\mathrm{p}=0.05)$. The median values by subgroup are presented in Fig. 2.

Moreover when we compare the median values for Ld and CRP from the third day with the correspondent values from the first day and then the values from the fifth day with the values from the third day, for both sub-samples we achieve different results. We present them in the Table 1.

The results from Table 1 are showing that the values of medians for both indicators CRP and Ld are not statistically different from one 
250

207.2

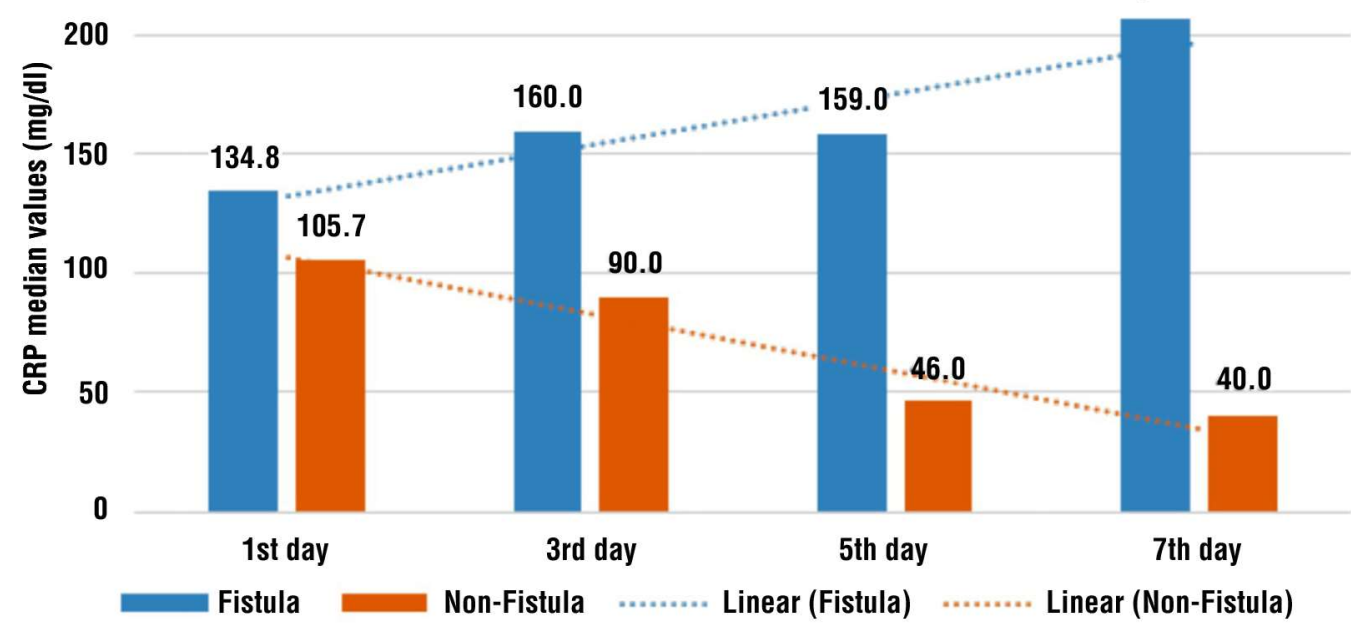

Figure 1. The CRP dynamics for the two groups of patients with fistula vs. non-fistula

Table 1. Statistical results in the case of median test for both subgroups of patients

\begin{tabular}{lcccc}
\hline Significance levels & \multicolumn{2}{c}{ No fistulas patients } & \multicolumn{2}{c}{ Patients with fistulas } \\
\hline Median compared & Signed Test & Wilcoxon Signed Rank & Sign Test & Wilcoxon Signed Rank \\
\hline CRP1 vs. CRP3 & $p=0.05$ & $p=0.07$ & $p=0.80$ & $p=0.20$ \\
\hline CRP3 vs. CRP5 & $p<0.01$ & $p<0.01$ & $p=0.98$ & $p=0.63$ \\
\hline Ld1 vs. Ld3 & $p<0.01$ & $p<0.05$ & $p=0.18$ & $p=0.08$ \\
\hline Ld3 vs. Ld5 & $p<0.01$ & $p=0.06$ & $p=1.0$ & $p=0.88$ \\
\hline
\end{tabular}

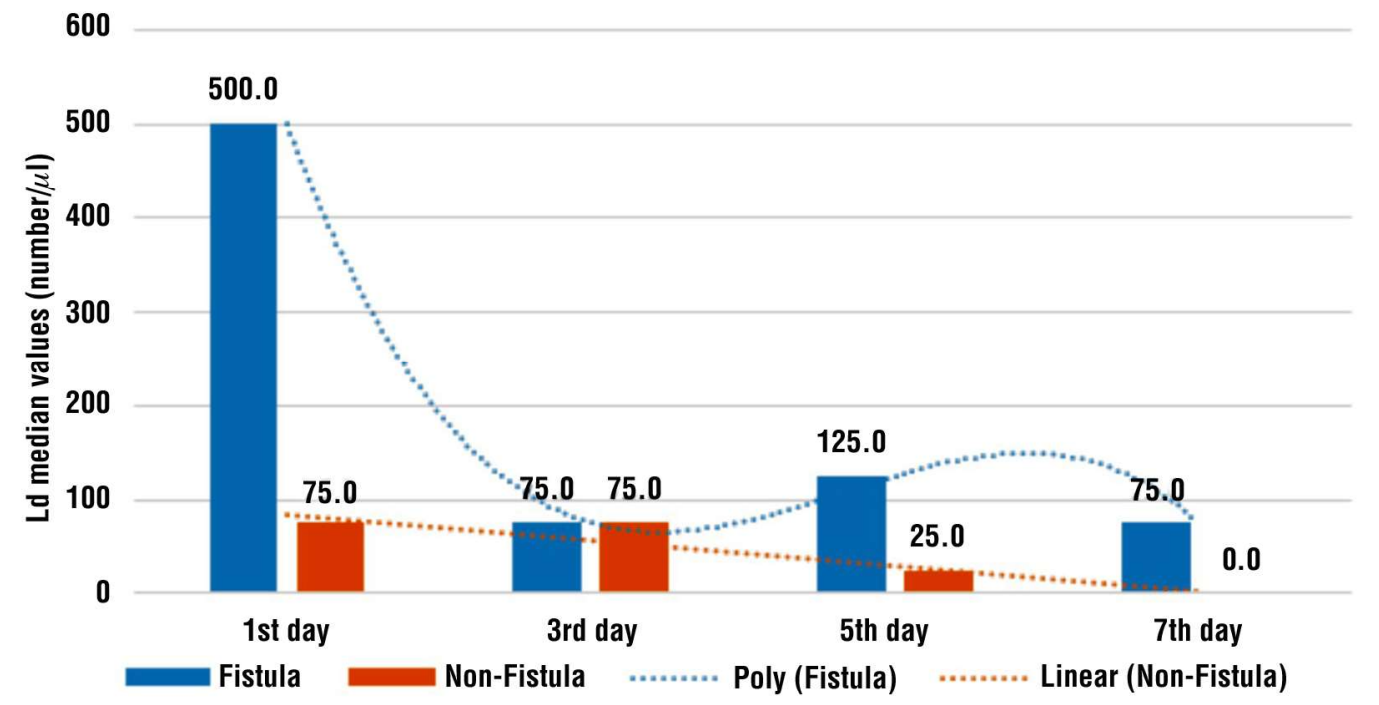

Figure 2. The Ld dynamics for the two groups of patients with fistula vs. non-fistula 
day to another for the patients with fistulas. In the sub-sample consisted by the patients with no fistula, the results are different. For both indicators, the values of medians are statistically different from one day to another. One difference should be treated with caution. The difference between the values of CRP for the first and the third day has risk very close to the 0.05 trash-hold in the case of Signed Test and a small excess $(p=0.07)$ in the case of Signed Rank Test.

\section{Stage 2}

When the Ld3 values are tested using the ROC curve we find an AUC of 0.648, which is not statistically greater than $0.5(\mathrm{p}=0.07)$. When the CRP values are examined with same methodology we achieve a value of 0.79 , statistically greater than $0.5(\mathrm{p}<0.01)$. In the case of dynamics of CRP and Ld here the CRP31 and Ld31 defined in the $1^{\text {st }}$ paragraph, the results are not statistically significant at levels lower than the 0.05 tresh-hold.

\section{Stage 3}

The Kendall correlation coefficients test are showing mainly non-significant relations at 0.05 level, but some exceptions may be underlined. The correlation between CRP and Ld in the third day is significant $(\mathrm{p}<0.05)$ and positive for no fistula group and negative for fistula group of patients. Also the correlation is stronger for the fistula group. All the values are presented in Table 2 .

\section{Discussions}

The issue of the early detection of anastomotic leak was debated in 2008 by Cornel Iancu and collaborators; they made a retrospective study on a batch of 993 patients who underwent surgery for colorectal neoplasm, and analysed several clinical and biological factors which could indicate the risk of fistula. The result was that a level of proteinemy under $5.5 \mathrm{~g} / \mathrm{dl}$ and a level of haemoglobin under $9.4 \mathrm{~g} / \mathrm{dl}$ are prediction factors for the risk of fistula (11).
In 1992, Lazorthes shows that the incidence of leaks in colorectal anastomosis is correlated with the level of anastomosis. Thus, the anastomosis situated at $3-4 \mathrm{~cm}$ from the anocutaneous line have a $30 \%$ incidence of fistulas, compared to the ones situated at $5 \mathrm{~cm}$, with a considerably low risk of developing fistulas. None other methods of protection of anastomosis have proven to be more efficient (12).

In 2010, Dekker et al. published a preoperative prediction score for the emergence of fistulas on the basis of which the physician can appreciate if performing an anastomosis or colostomy is indicated for a patient (13). The application of a score does not completely eliminate the risk of fistula, and that is why a study performed by Dulk et al (2009) analysed several clinical (fever, heart rate, ileum signs, gastric retention) and biological (CRP, leukocytosis, renal function) factors, trying to create a postoperative prediction score for the emergence of a fistula. The patients with a high score underwent a more attentive clinical and paraclinical observation. This score reduced the delay of fistula diagnosis from 4 to 1.5 days (9).

Freek Daams, in 2013 and then in 2014 $(4,8)$, consider CRP is a good indicator for postoperative infectious complications, but it is not specific for a fistula. Measuring cytokines from the peritoneal drained fluid is promising (14, 15) and while the peritoneal microdialysis

Table 2. The Kendall correlation coefficient values and related signficances levels

\begin{tabular}{lccc}
\hline \multicolumn{2}{l}{ Correlated measures } & \multicolumn{2}{c}{ Kendall correlation coefficient values } \\
\hline & & No fistula group & Fistula group \\
\hline CRP1 & Ld1 & 0.05 & -0.11 \\
& Ls1 & 0.09 & 0.12 \\
\hline CRP3 & Ld3 & 0.2 & -0.45 \\
& & $p<0.05$ & $p<0.05$ \\
\cline { 2 - 4 } & Ls3 & 0.2 & -0.03 \\
& & $p<0.01$ & \\
\hline CRP5 & Ld5 & 0.14 & 0.06 \\
& Ls5 & 0.23 & -0.04 \\
& & $p<0.01$ & \\
\hline Ld1 & Ls1 & 0.06 & 0.03 \\
\hline Ld3 & Ls3 & 0.1 & 0.1 \\
\hline Ld5 & Ls5 & -0.05 & -0.21 \\
\hline
\end{tabular}


(10), but haven't shown a significant statistical predictive value in the case of patients without clinical symptomatology $(16,17)$. The authors of the articles mentioned above state that other studies are necessary to confirm the clinical value of this score, by introducing the parameters obtained in current clinical treatment protocols and which would allow the early surgical reintervention of these patients before the emergence of sepsis $(18,19)$.

For the anastomosis performed in the surgical interventions of the colon, CRP has high postoperative values in all patients, with average values in the first day of $119.18 \mathrm{mg} / \mathrm{dl}$, but with higher values in those who will develop a fistula $(169.66 \mathrm{mg} / \mathrm{dl})$ as compared to those without a fistula $(113.42 \mathrm{mg} / \mathrm{dl})$. In the case of patients without a fistula the trend is a progressive drop in the postoperative first, third and fifth day (101.93-51.06-49.89 mg/dl); the patients with fistula CRP the trend is high, or after a slow decrease in the third day the values increase again in the postoperative seventh day (128.16-105.83-123.00mg/dl), this day having an average value, when the fistula was discovered through clinical and paraclinical methods. The value of CRP of 128.16 $\mathrm{mg} / \mathrm{dl}$ or greater from the postoperative third day should be a wake-up call as to the evolution of anastomosis and the possibility of fistula emergence.

With regard to the number of $\mathrm{Ld}$, it was found that in the first postoperative day the average values are greater in patients without fistula, decreasing in the third, fifth and seventh day. In patients with fistula, the decrease was slower, the high values being maintained (from 266.66 in the first day to

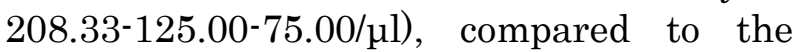
patients without fistula (from 465.00 in the first day to $128.83-117.44-70.00 / \mu l)$. We found that the number of leukocytes in the peritoneum increased a day or two before the clinical manifestation of the fistula or it remained high, close to the values in the first postoperative day

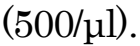

We found that some intraperitoneal drains close to the anastomosis are isolated and either they do not drain any more, either the number of leukocytes is zero, thus we decided to collect fluid from Douglas pouch. Even if the tube was situated at distance from the anastomosis, in the event of a fistula there was an increase in the number of leukocytes collected at this level. Practically, after the first cases monitored, we decided to collect leukocytes from any of the intraperitoneal drains, or to be more exact from the one that drained more. As a general rule, we place surgical drains in all surgical procedures, with the drains close to the anastomosis areas and at the level of Douglas pouch. Even if routine placing of peritoneal drains is not recommended by the literature, we consider that placing multiperforated drains perianastomotically and in the Douglas pouch constitutes an advantage because it allows a rapid diagnosis of fistula (20).

The leukocytosis was on average above normal in the first day, higher in patients with fistula (13740.00/ $\mathrm{LL})$ compared with patients without fistula $(11641.20 / \mu \mathrm{L})$. The number of leukocytes increased one or two days before the emergence of fistula. Due to the septicity of the colon and the intraoperative contamination, the inflammatory reaction (CRP) is more intense as compared to the surgical interventions of the stomach (169.66 compared to $132.82 \mathrm{mg} / \mathrm{dl}$ in patients with fistula in the first day).

A high value of CRP maintained after the third postoperative day, with low values of leukocytes in the peritoneal drain, but with leukocytosis, indicated the emergence of other complications: bronchopneumonia, the infection of the wound, etc., but not digestive fistula.

We monitored the same parameters for the anastomosis performed for the surgical treatment of gastric tumours. The CRP in the first day in patients with fistula had average values lower than in the case of surgical interventions on the colon (132.82, compared to $169.66 \mathrm{mg} / \mathrm{dl}$ ), but the values increased progressively in the third, fifth and seventh day (188.43-224.23-254.24 mg/dl). The patients who had a good evolution had average values of $109.80 \mathrm{mg} / \mathrm{dl}$ in the first day, and then a descending evolution of CRP in the same day $(99.75-60.15-36.21 \mathrm{mg} / \mathrm{dl})$. 
The number of Ld was high in the first day in patients with fistula $(340.62 / \mu \mathrm{l})$, and after a slight decrease in the third day $(218.75 / \mu l)$ it registered an important increase in the fifth day $(307.14 / \mu 1)$, probably that was the moment when the fistula was produced. After the emergence of the fistula, the number of leukocytes decreased in the seventh day (150/ul). In patients without fistula the trend was a

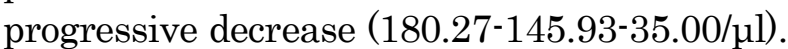

The Ls followed the same trend with the Ld until the fifth day (14571.25-10515.00-12785.00 $/ \mu 1)$, but with an important increase (16243.75/ ul) in the seventh day when the fistula was diagnosed through clinical investigations and imaging.

The Independent sample median test shows that patients with fistula have significant higher values of CRP than the no-fistula group, especially in the third and fifth day after the intervention. The values of Ld are significant higher only in the 5th day when both groups are compared.

In dynamics for the fistula patients the median values are not statistically different from one day to another in the case of CRP and Ld. For the patients with fistula both CRP and Ld have high values in all days, while for the non-fistula group the values are decreasing day by day.

The Kendall cofficients tested for the correlation between CRP, Ld and Ls pairs, are showing that in the third day, a positive and statistically significant $(\mathrm{p}<0.05)$ correlation between CRP and Ld3 for the non-fistula patients. This implies that an increases of $\mathrm{CRP}$ values in the third day is associated with and increase of $\operatorname{Ld} 3$ values in the same day for the non-fistula patients. For the fistula patients the correlation is also significant $(p<0.05)$ but negative, showing then that lower values of CRP among patients with fistula, in the third day, is rather associated with higher values in $\mathrm{Ld}$ in the same day.

The ROC curve analysis shows that the CRP is a better predictor than $\mathrm{LD}$ of fistula presence in the third day after the intervention.
Taking all things into account we may conclude that the values seen in the fifth day may be anticipated by an analysis taken in the third day reducing the waiting time, possible complications and finally increasing the quality of patient treatment and saving costs.

The originality of the study consists of analyzing two biological blood markers (CRP, leukocytosis) and a peritoneal biologic marker (the number of leukocytes) in an attempt to establish a prediction score for anastomotic fistula in patients with digestive cancer. The marker in the peritoneal fluid exteriorized on the juxta-anastomotic drainage tubes will increase the specificity of the results from the singular analysis of the CRP which is known to be a non-specific inflammatory marker. The elimination of subjective clinical factors will increase the objectivity of the results. We mention that digestive sutures were made both manually and mechanically and were not analyzed separately.

We consider that the association of CRP to the assessment of leukocytes from the peritoneal fluid could trigger an alarming sign in the third postoperative day as to the possibility of fistula emergence and could help in establishing some active measures: careful monitoring and supplementation of laboratory and imagistic investigations (CT with contrast medium), broad-spectrum antibiotic or association of antibiotics, the suppression of enteral feeding and starting the parenteral feeding, draining under CT guidance or early reintervention (laparoscopic, classic). Practically, we could state that the emergence of a fistula could be diagnosed 2-3 days before its clinical and imagistic manifestation, and we consider the number of leukocytes from the peritoneal drainage to be more faithful criteria than measuring the leukocytes collected from the blood.

The results we obtained could represent preliminary data for new subjects or research directions which can lead to analyse of other markers (procalcitonin), in such a way that the clinical value of results increase $(21,22)$. 


\section{Conclusions}

Regular and standardized monitoring of the CRP value, of the number of leukocytes in the peritoneum and of leukocytosis in the 1st, 3rd and 5th postoperative day allows an early identification of patients having a risk of fistula, and assures a rapid selection of those who need supplementary explorations and/or surgical procedure.

Even if the issue of gastro-colic fistulas was frequently a reason for analysis because of the septic severe complications they generate, with a high mortality and morbidity, until now the studies performed did not manage to considerably enhance the evolution of these patients. Starting from the well-known severity of intraperitoneal septic complications, we can affirm that we should do everything in our power to prevent them, and this is the exact purpose of this article.

We consider that the article has a social and economic impact because the early identification of anastomotic fistulas in digestive cancer surgery allows avoiding the emergence of septic intraperitoneal complications and decreasing the costs for patients' care in the hospital and the costs created by the temporary incapacity for work. Another element with economic impact is that the testing of the markers we proposed does not need equipment and costly supplies, and can be performed in hospitals with minimal equipment.

\section{Conflict of Interest}

The authors declared no conflict of interest.

\section{References}

1. Radulescu D, Belusica L. Caiete de chirurgie practica. Vol. II, Editia a II-a. Bucuresti: Ed. Medicala; 1999, p. 111-128.

2. Vignali A, Fazio VW, Lavery IC, et al. Factors associated with the occurrence of leaks in stapled rectal anastomoses: a review of 1,014 patients. J Am Coll Surg. 1997;185(2):105-13.

3. Daams F, Luyer M, Lange JF. Colorectal anastomotic leakage: Aspects of prevention, detection and treatment. World $\mathrm{J}$ Gastroenterol. 2013;19(15):2293-2297.

4. Straatman J., Cuesta MA, de Lange-de Klerk ES, van der Peet DL. Hospital. Cost-analysis of complications after major abdominal surgery. Dig Surg. 2015;32(2):150-6.
5. Lindgren R, Hallböök 0, Rutegțrd J, Sjödahl R, Matthiessen P. What is the risk for a permanent stoma after low anterior resection of the rectum for cancer? A six-year follow-up of a multicenter trial. Dis Colon Rectum. 2011;54(1):41-7.

6. Rullier E, Laurent C, Garrelon JL, Michel P, Saric J, Parneix M. Risk factors for anastomotic leakage after resection of rectal cancer. $\mathrm{Br}$ J Surg. 1998;85(3):355-8.

7. Daams F, Wu Z, Lahaye MJ, Jeekel J, Lange JF. Prediction and diagnosis of colorectal anastomotic leakage: A systematic review of literature. World J Gastrointest Surg 2014;6(2):14-26.

8. den Dulk M, Noter SL, Hendriks ER, Brouwers MA, van der Vlies $\mathrm{CH}$, Oostenbroek RJ, et al. Improved diagnosis and treatment of anastomotic leakage after colorectal surgery. Eur J Surg Oncol. 2009;35(4):420-6.

9. Matthiessen P, Strand I, Jansson K, Törnquist C, Andersson M, Rutegțrd J, et al. Is early detection of anastomotic leakage possible by intraperitoneal microdialysis and intraperitoneal cytokines after anterior resection of the rectum for cancer? Dis Colon Rectum. 2007;50(11):1918-27.

10. Iancu C, Mocan LC, Todea-Iancu D, Mocan T, Acalovschi I, Ionescu $D$, et al. Host-related predictive factors for anastomotic leakage following large bowel resections for colorectal cancer. J Gastrointestin Liver Dis. 2008;17(3):299-303.

11. Lazorthes F, Chiotasso P, Gamagami RA, Istvan G, Chevreau P.. Late clinical outcome in a randomized prospective comparison of colonic $\mathrm{J}$ pouch and straight coloanal anastomosis. $\mathrm{Br} \mathrm{J}$ Surg. 1997;84(10):1449-51.

12. Dekker JW, Liefers GJ, de Mol van Otterloo JC, Putter H, Tollenaar RA. Predicting the risk of anastomotic leakage in left-sided colorectal surgery using a colon leakage score. J Surg Res.2011; 166:e27-e34

13. Yamamoto T, Umegae S, Matsumoto K, Saniabadi AR. Peritoneal cytokines as early markers of peritonitis following surgery for colorectal carcinoma: a prospective study. Cytokine. 2011; 53(2): 239-42.

14. Tsujinaka S, Kawamura YJ, Konishi F, Maeda T, Mizokami K. Pelvic drainage for anterior resection revisited: use of drains in anastomotic leaks. ANZ J Surg. 2008;78(6):461-5.

15. Karliczek A, Benaron DA, Baas PC, Zeebregts CJ, Wiggers T, van Dam GM. Intraoperative assessment of microperfusion with visible light spectroscopy for prediction of anastomotic leakage in colorectal anastomoses. Colorectal Dis. 2010;12(10):1018-25.

16. Sheridan WG, Lowndes RH, Young HL. Tissue oxygen tension as a predictor of colonic anastomotic healing. Dis Colon Rectum. 1987; 30(11):867-71.

17. Hirano $\mathrm{Y}$, Omura K, Tatsuzawa $\mathrm{Y}$, Shimizu J, Kawaura $\mathrm{Y}$, Watanabe $G$. Tissue oxygen saturation during colorectal surgery measured by near-infrared spectroscopy: pilot study to predict anastomotic complications. World J Surg. 2006;30(3):457-61.

18. Ellebaek Pedersen M, Qvist N, Bisgaard C, Kelly U, Bernhard A, Møller Pedersen S. Peritoneal microdialysis. Early diagnosis of anastomotic leakage after low anterior resection for rectosigmoid cancer. Scand J Surg. 2009;98(3):148-54.

19. Thomas HA. Radiologic investigation and treatment of gastrointestinal fistulas. Surg Clin North Am. 1996;76(5):1081-94.

20. Giaccaglia V, Salvi PF, Antonelli MS, Nigri G, Pirozzi F, Casagranda B, et al. Procalcitonin Reveals Early Dehiscence in Colorectal Surgery: The PREDICS Study. Ann Surg. 2016; 263(5):967-72.

21. Nahm FS. Nonparametric statistical tests for the continuous data: the basic concept and the practical use, Korean $\mathrm{J}$ Anesthesiol. 2016;69(1):8-14

22. Krzywinski M, Altman N. Points of Significance: Nonparametric tests. Nat Methods. 2014;11(5):467-8.

23. Kendall MG. A New Measure of Rank Correlation. Biometrika. 1938;30(1-2):81-93. 